\title{
Spatial diversification of selected demographic phenomena in Polish communes
}

\author{
Beata Bal-Domańska* \\ Wrocław University of Economics \\ Faculty of Regional Economy and Tourism in Jelenia Góra \\ 3 Nowowiejska Street, 58-562 Jelenia Góra, Poland \\ *beata.bal-domanska@ue.wroc.pl
}

\begin{abstract}
Demographic potential constitutes one of the most important aspects of socioeconomic development by exerting impact on the growth potential and directions of the policy carried out at local and regional level. The areas concentrating young people, characterized by high birth rate and a positive migration balance gain growth potential not only for their current but also long-term development. The objective of the article is to present spatial diversification of the selected demographic phenomena in the cross-section of Polish communes in 2011 as well as to indicate areas presenting high and low growth potential.
\end{abstract}

Key words: demographic changes; natural increase; migration balance; age dependency ratio; municipalities; Poland

Received: 2 Feb 2014 - Accepted: 8 Jun 2014

\section{Introduction}

Demographic potential constitutes one of the most important aspects of socio-economic growth by influencing both developmental potential and the directions of policy carried out at the local and regional level.

The changes observed in recent years, in terms of demography, indicate several trends, such as the prolonged average life expectancy (in accordance with EUROSTAT data life expectancy in the European Union in 2011 was 80,4 years, in Poland - 76,9). The next tendency, having certain consequences in the socio-economic situation of countries and regions, refers to women fertility rate. The natural level of this particular rate, which ensures maintaining the same level of population, is 2.1 , i.e. 2.1 children fall per every woman. In Poland the discussed rate presents one of the lowest values in the cross-section of EU countries and in 2011 it was 1.3, i.e. much less than the natural generation replacement level.

In this context the demographic processes occurring in particular regions are of utmost importance. The areas concentrating young people, characterized by high birth rate and a positive net migration, gain developmental potential not only in terms of their current, but also long-term, growth. The objective of the article is to present spatial diversification of the selected demographic phenomena in the crosssection of Polish municipalities in 2011.

\section{Research procedure}

The characteristics of transformations occurring in the population number, based on data regarding the actual population growth rate in municipalities in 2011 against 2010, became the starting point for the presented analysis. Next the author discussed spatial diversification of the problems related to:

- migration for permanent residence (internal and foreign (international)),

- natural increase (number of births and deaths),

- population structure by economic age groups.

The presented problems were summarized in the form of a presentation illustrating the ranking results of municipalities in line with the aggregate measure of growth (AMG) (Hellwig 1968; Dziechciarz 2003 ed.; Walesiak 2006; Bal- 
Domańska, Wilk 2011). It has a multi-stage construction consisting of the following stages:

1. Defining diagnostic characteristics and determining their nature/significance for the description of a particular research aspect (stimulants, nominats and destimulants). The measure was constructed based on three diagnostic characteristics describing the defined areas, such as:

- total net migration per 10000 inhabitant,

- natural increase per 10000 inhabitant,

- age dependency ratio (non-productive age population per 100 working age people).

2. The initial data analysis characterizing the level and diversification of the examined phenomena. Particular attention was focused on the outermost values, i.e. the highest and the lowest.

3. Normalization of diagnostic characteristics using zero unitarization method. The application of unitarization formula results in obtaining values for all diagnostic characteristics in the range $[0,1]$, with " 0 " value adopted by a unit for which the characteristics equal the minimal value ( ), whereas "1" - for maximum value ( ).

4. The unification of characteristics, from the perspective of the conducted analysis goal, by changing destimulants $z D$ into stimulants $z S$.

5. Determining the coordinates of a reference object. The reference object is defined by the best indicator values. The top development pattern was adopted as the reference point, i.e. maximum values were considered the best values of diagnostic characteristics in case of stimulants, and minimal values for destimulants.

6. Specifying the aggregate measure of growth (AMG) using the standardized sums method. Higher growth measure values indicate a relatively favourable situation of a given territorial unit at the background of others.

\section{Population growth rate}

In 2011 the number of Polish population was 38 538447 and was higher by 8581 people comparing to 2010. The population growth rate was $0.002 \%$. From among 2479 municipalities almost 56\% i.e. 1387 units recorded their population number decline (Fig. 1). The largest population number drop, by $-3.3 \%$, was recorded in the rural municipality of Dubicze Cerkiewne (Łomżyński sub-region). Large population number decrease (more then $2 \%$ ) was also observed in rural municipalities: Sosnówka, Orla and Lubochnia, as well as in the town of Hel. On the other hand, the largest growth rate occurred in the municipalities of Poznański sub-region: Komorniki, Dopniewo, Rokietnica (about 6\%) and Stawiguda municipality in Olsztyński sub-region (6.5\%).

These changes in the population number were largely dependent on a given municipality location. As the data presented in Fig. 1 show, strong sub-urbanization processes are visible and manifested by the population number growth in municipalities neighbouring large cities. This situation was particularly visible in 2011 in the areas surrounding such cities as Warsaw, Tri-city (Gdańsk, Gdynia, Sopot), Wrocław, Szczecin, Białystok, Bydgoszcz and Toruń, Koszalin, Poznań, Kraków, Lublin, Płock, Olsztyn, Legnica, Gorzów Wlkp., and among the cities populated by less than 100000 inhabitants: Leszno, Gniezno, Turek, Lublin and Głogów.

Many municipalities of eastern and central Poland recorded a drop in the number of population. The population number changes in particular municipalities resulted from the level of permanent residence net migration and birth rate determined by the number of births and deaths. These problems will be discussed later within the scope of this study. 


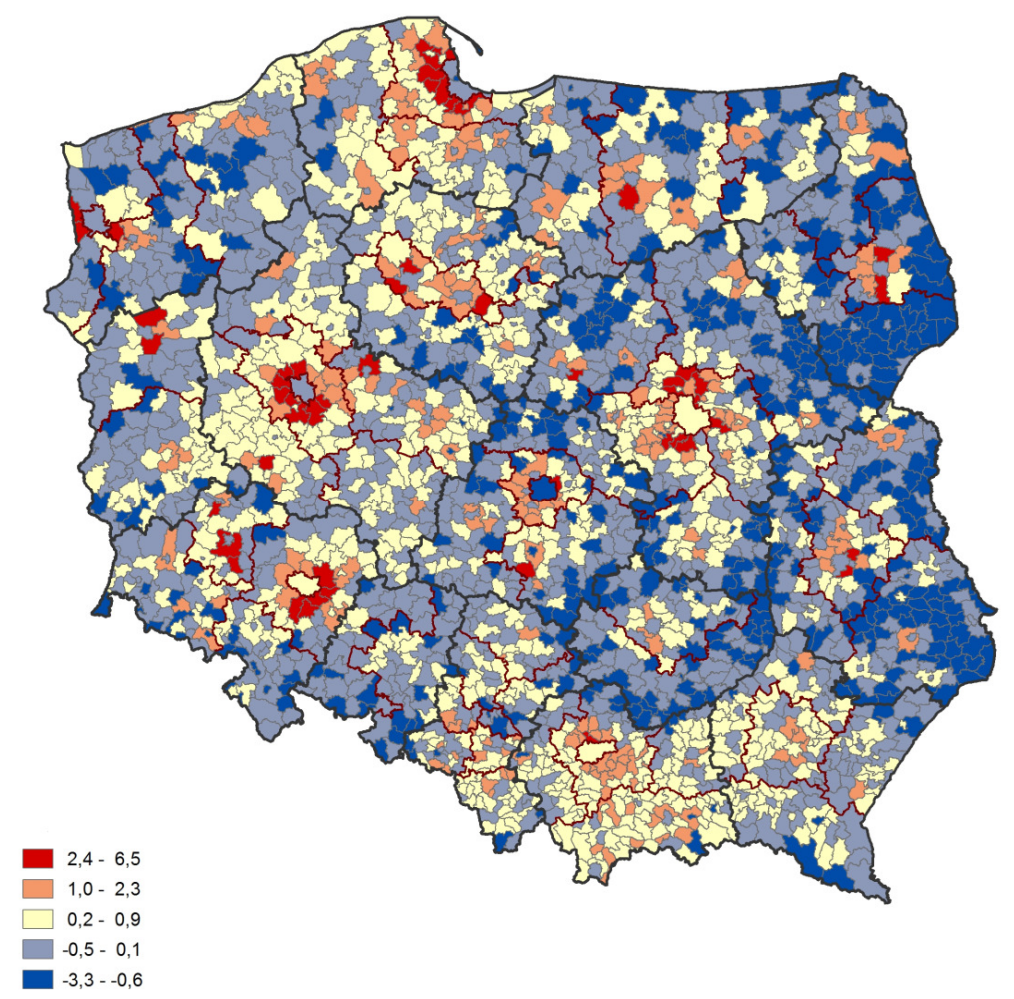

Fig. 1: Population growth rate in 2011 comparing to 2010 (\%). Source: Compilation based on the data available in the Local Data Bank of the Central Statistical Office.

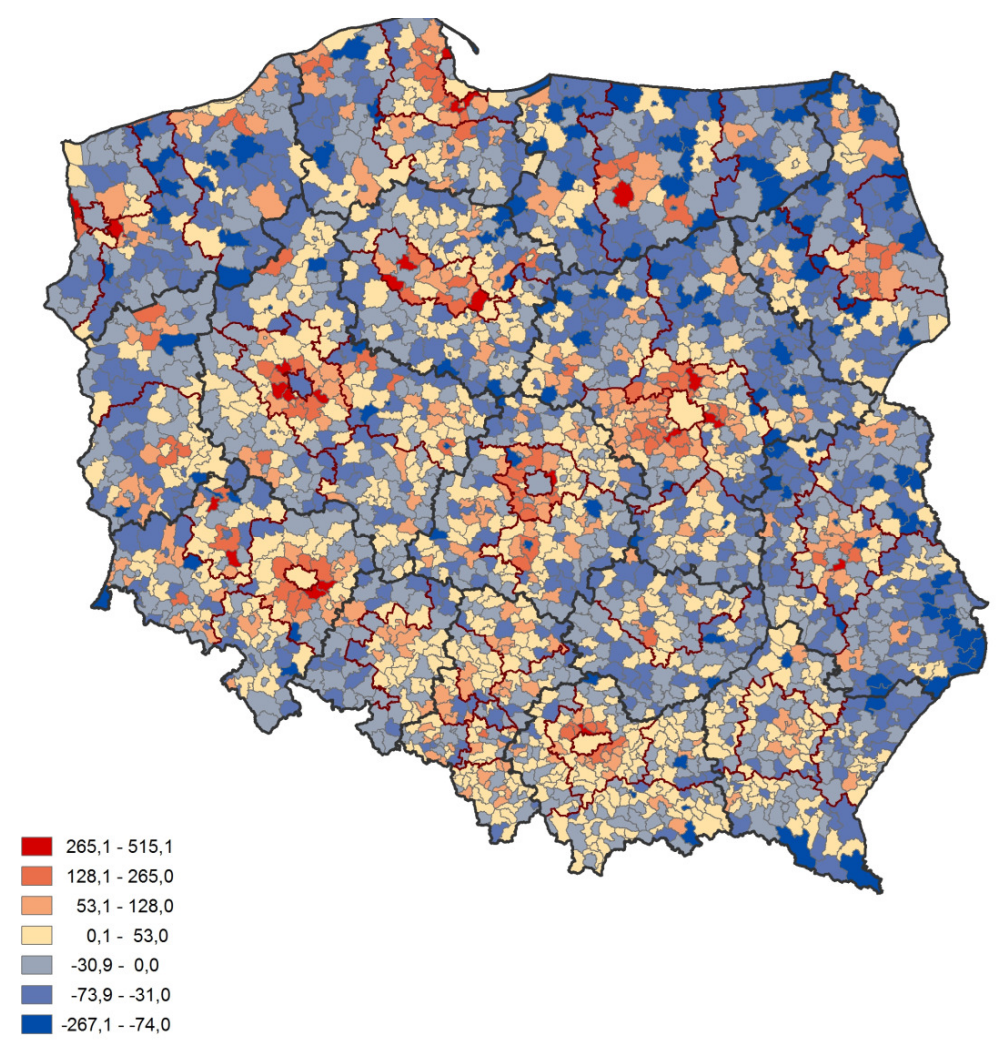

Fig. 2: Internal net migration in 2011. Source: Compilation based on the data available in the Local Data Bank of the Central Statistical Office. 


\section{VERSIT $\Lambda$}

\section{Internal and international net migration}

Permanent residence migrations are divided into internal ones, resulting from the change of permanent address by population within the country, so e.g. between municipalities, and foreign (international) ones, which refer to changing the address as the result of moving from abroad or to abroad.

From among 2479 municipalities in $58 \%$ of them (i.e. in 1438) the negative internal permanent residence net migration was recorded (Fig. 2). In the remaining 1041 the internal net migration was positive or equal zero. In 2011 the population inflow, within internal traffic, towards the area of large cities, such as: Wrocław, Poznań, Szczecin, Tri-city (Gdańsk, Gdynia, Sopot), Bydgoszcz and Toruń, Łódź, Warsaw, Białystok, Olsztyn and Cracow, Białystok and Gorzów Wielkopolski, was observed. The lowest positive internal permanent residence net migration per 10000 inhabitants was recorded in the following rural municipalities: Stawiguda (515.1 people), Rokietnica (482.2), Dobra Szczecińska (466.6) and Dopiewo (460.0).
The largest population deficits in internal traffic (over 30 people per 10000 inhabitants) were recorded, in 2011, in many municipalities of such sub-regions as: Łomżyński, Puławski, ChełmskoZamojski and Elbląski. In 46 municipalities the negative internal net migration exceeded 100 people per 10000 inhabitants and in case of two (the urban municipality of $\mathrm{Hel}$ and the rural municipality of Lubochnia) the deficit was higher than 250 people per 10000 inhabitants. From among the cities with district rights the highest negative permanent residence net migration in internal traffic was recorded in: Ostrołęka, Jastrzębie Zdrój and Konin.

Net foreign net migrations for permanent residence, calculated per 10000 inhabitants in domestic scale, was negative and amounted to 1.1 people, which means that more people changed their permanent address as the result of moving abroad from Poland than arriving to Poland from abroad (Fig. 3).

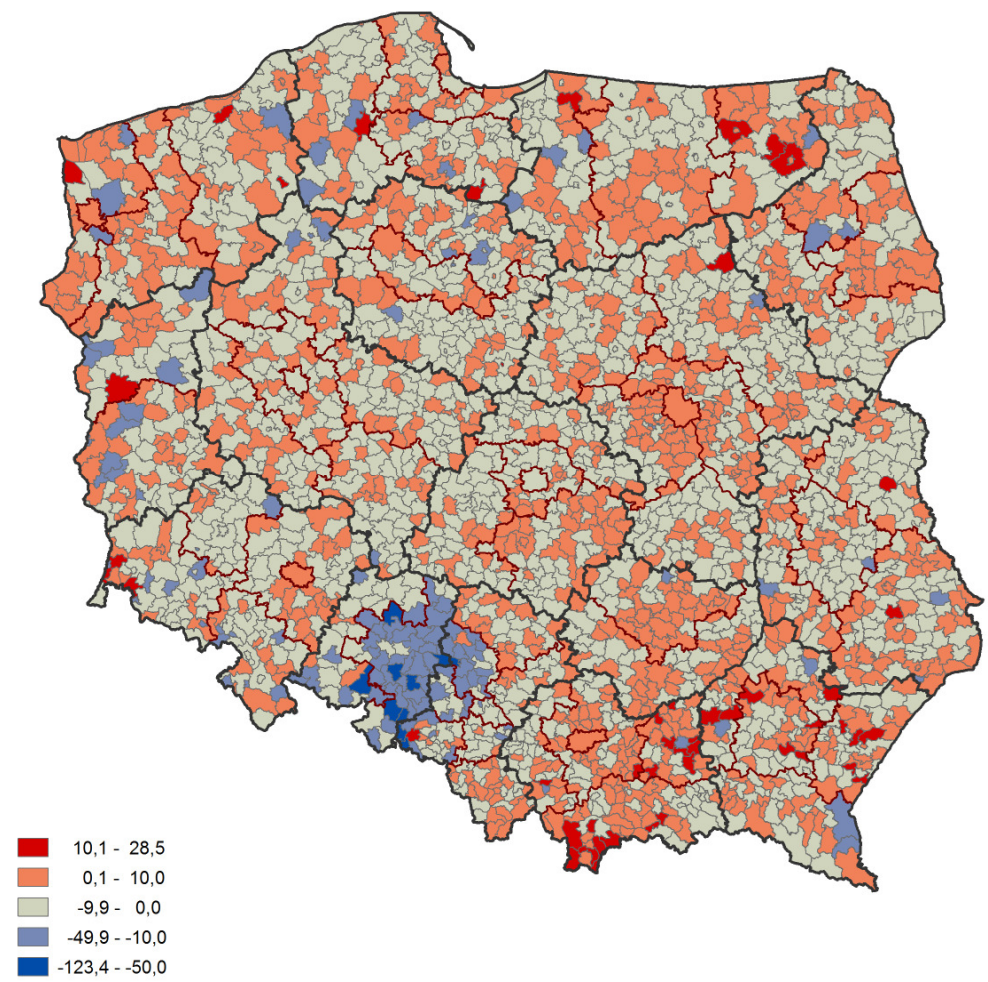

Fig. 3: International (foreign) net migration in 2011. Source: Compilation based on the data available in the Local Data Bank of the Central Statistical Office. 


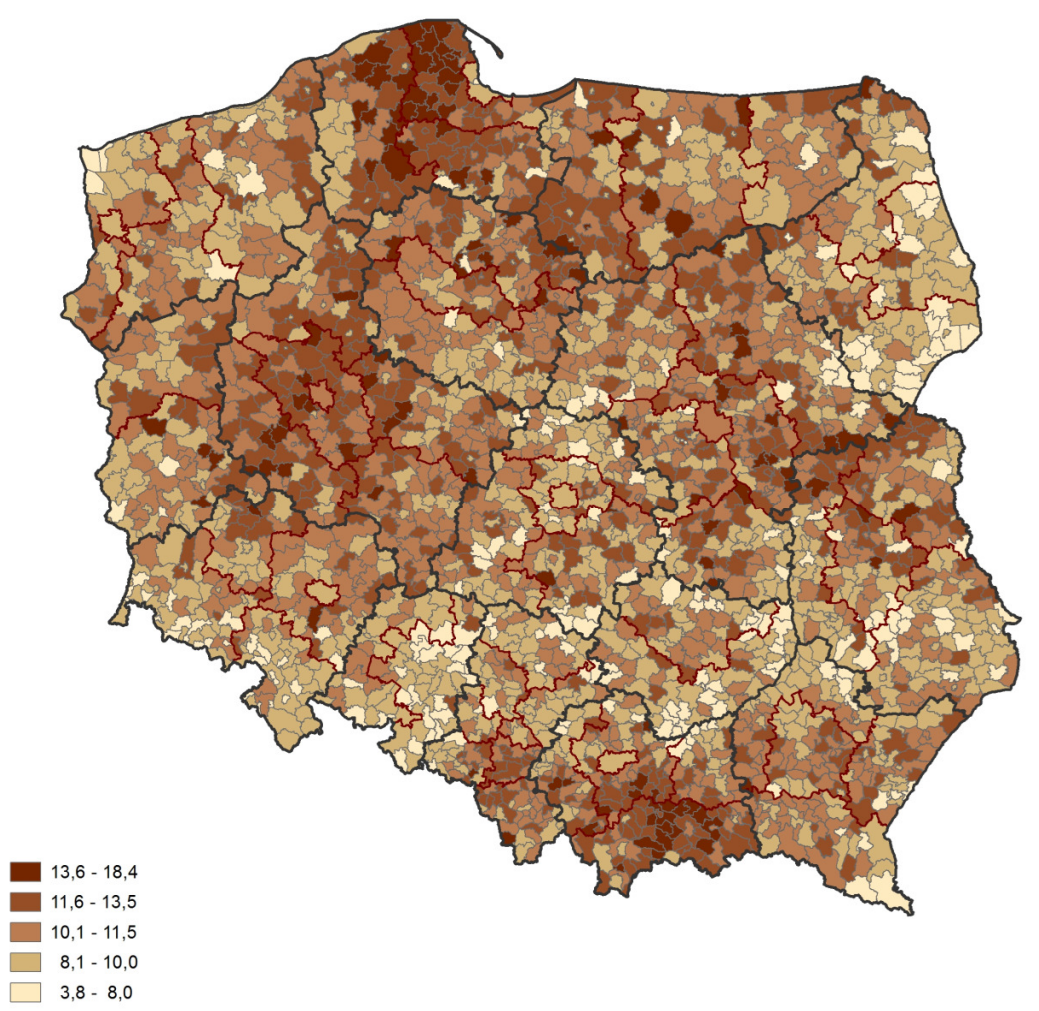

Fig. 4: Live births per 1000 inhabitants in 2011. Source: Compilation based on the data available in the Local Data Bank of the Central Statistical Office.

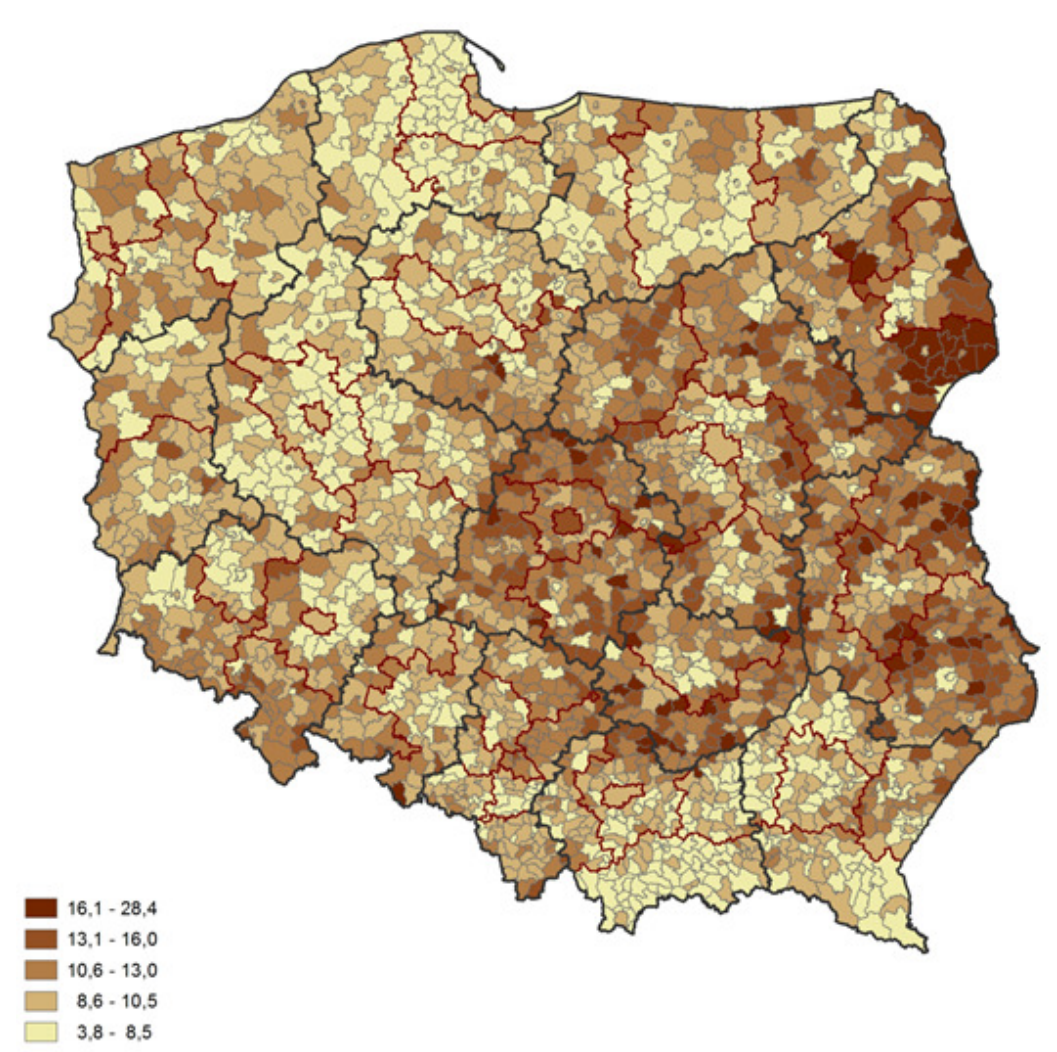

Fig. 5: Deaths per 1000 inhabitants in 2011. Source: Compilation based on the data available in the Local Data Bank of the Central Statistical Office. 
In the cross-section of municipalities the net from abroad migrations per 10000 inhabitants ranged from minus 123.4 (Pietrowice Wielkie rural municipality, Rubnicki sub-region) to 28.5 (Poronin rural municipality, Nowosądecki subregion).

In 847 municipalities the negative net from abroad migration rate was recorded, whereas positive in 935 and in case of the remaining 697 it equalled zero. No registrations for permanent address of population arriving from abroad were recorded in 710 municipalities and no changes of permanent address regarding to abroad migrations were reported in 1084 municipalities.

The following rural municipalities recorded the highest positive net migration of population arriving from abroad (more than 20 calculated per 10000 inhabitants): Poronin (28,5), Płoskinia (26.5), Stare Juchy (25.2) and Giżycko (21.0).

The highest negative net to abroad migrations, calculated per 10000 inhabitants, was recorded in the municipalities of Opolski and Bytomski subregions. In case of Opolski sub-region all 43 municipalities reported a negative net to abroad migration rate, while out of 19 Bytomski district municipalities in 17 the net to abroad migration was negative. The municipalities which recorded the highest negative values of net to abroad migrations were the following rural municipalities: Pietrowice Wielkie (-123.4) and Polska Cerekiew (- 114.5).

The most frequent to abroad migrations referred to the population aged $25-45$, of which people aged 28-32 constituted the largest group moving abroad. The age structure of population arriving from abroad is similar to the structure of emigrants. The largest number of people coming from abroad represented the age group of 24-33 and along with older age the number of arrivals from abroad was gradually decreasing. In 2011, out of all immigrants, $17 \%$ represent children aged less than 1 year, while $28 \%$ were children up to two years of age.

\section{Natural increase}

Natural increase is influenced by two factors: births and deaths. In 2011 the number of live births per 1000 inhabitants presented the level of
10.1 in Poland and it ranged from 3,8 (in the rural municipality of Czyże, Łomżyński sub-region) to over 18.0 (in the rural municipalities of Parchowo, Słupski sub-region - 18.4 and Komorniki, Poznański sub-region - 18.2).

A large number of births per 1000 inhabitants was observed in many municipalities of the following sub-regions: Gdański (which mainly referred to four rural municipalities: Gniewino, Łęczyce, Przodkowo and Sierakowice), Poznański, Nowosądecki, Warszawski Wschodni, Leszczyński, Starogardzki. Among cities with district rights, in 2011, the largest number of children per 1000 inhabitants (more than 11) were born in Siedlce, Żory, Warsaw and Skierniewice, whereas the smallest number of children (less than 7) were born in Sopot, Jelenia Góra, Świnoujście and Przemyśl (Fig. 4).

Much more extensive differences were visible in the spatial distribution of the number of deaths (Fig. 5). This rate value for Poland, in 2011, calculated per 1000 inhabitants was 9.7. As far as the spatial distribution of the number of deaths per 1000 inhabitants in municipalities is concerned, it ranged from 3.8 (Kosakowo rural municipality, Gdański sub-region) up to 28.4 (Orla rural municipality, Łomżyński sub-region). Relatively lowest death rate values were reported in many municipalities of Gdański, Poznański and Nowosądecki sub-regions.

The highest death rate values were recorded in many municipalities of central and eastern Poland and it mainly referred to particular municipalities of the following sub-regions: Łomżyński (rural municipalities: Orla, Dubicze Cerkiewne and urban-rural municipality of Kleszczele), Sandomiersko-Jędrzejowski, Sosnowiecki, Łódzki, Skierniewicki. Among cities with district rights the highest deaths rate was registered in 2011 in Lodz.

In Poland the level of birth rate in 2011 was 0.3 per 10000 inhabitants. In $46 \%$ of municipalities (i.e. 1136) negative birth rate was recorded and in five municipalities it amounted to over minus 150 people per 10000 inhabitants, which occurred in the following municipalities: Orla rural municipality, Dubicze Cerkiewne rural municipality, Kleszczele rural-urban municipality, Rybczewice rural municipality and Rudnik rural 


\section{VERSITA}

municipality. In 40 municipalities birth rate led 0 and in the remaining $53 \%$ municipalities (i.e. $1303)$ it presented positive values. The highest birth rate values (more than 110 per 10000 inhabitants) were recorded in the following rural municipalities: Komorniki (Poznański sub-region), Sierakowice and Przodkowo (Gdański sub-region).

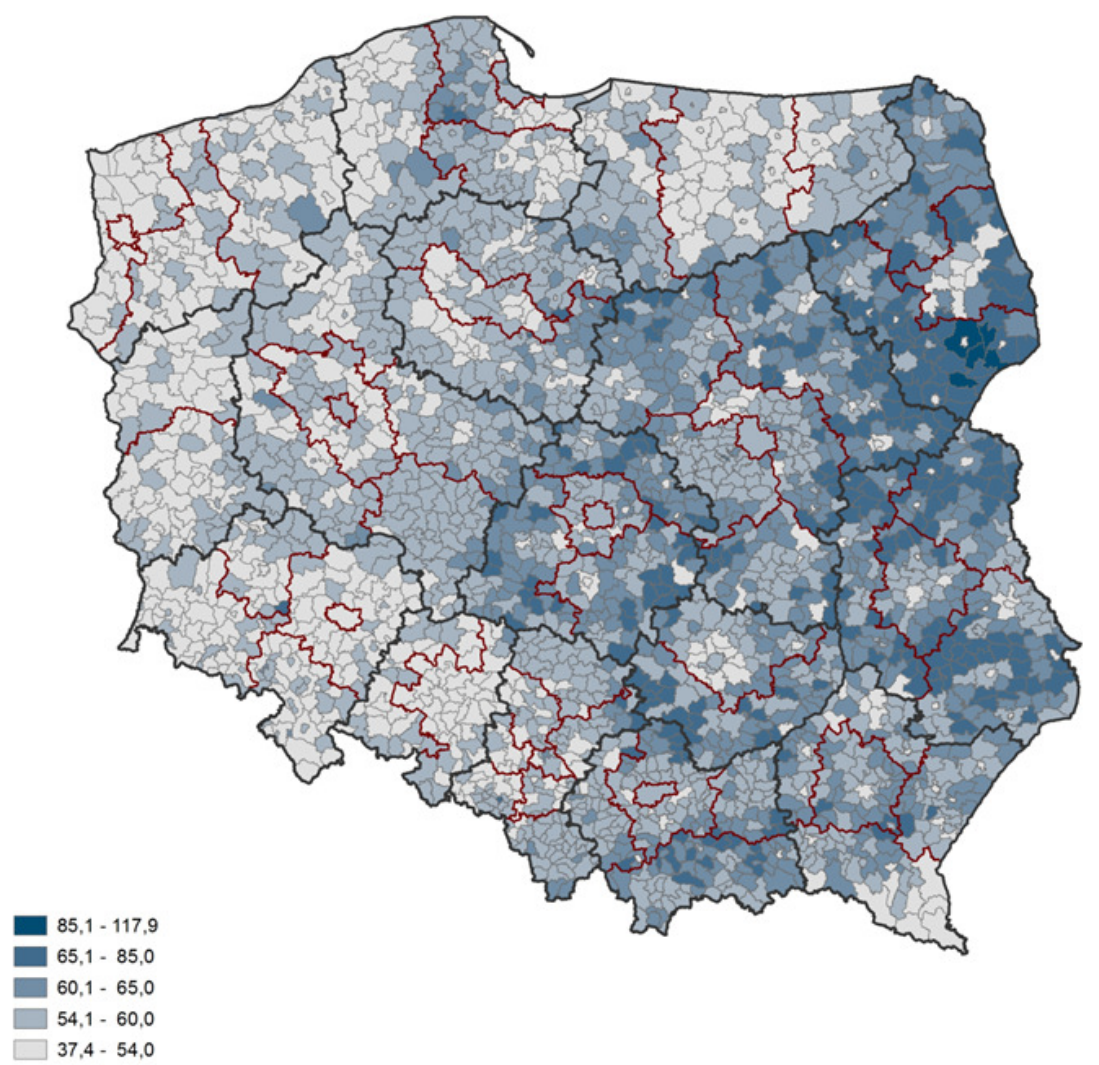

Fig. 6: Age dependency ratio in 2011. Source: Compilation based on the data available in the Local Data Bank of the Central Statistical Office.

Tab. 1: Municipalities by the level of aggregate measure of growth (AGM) in Poland in 2011. Source: Author's estimations based on the data available in the Local Data Bank of the Central Statistical Office.

\begin{tabular}{llrrr} 
Specification & AMG value & \multicolumn{1}{c}{$\begin{array}{l}\text { Number (\% share) of } \\
\text { municipalities presenting } \\
\text { particular demographic situation }\end{array}$} \\
\hline The highest AMG values & very good & & 8 & 0,3 \\
& good & $(0,801 ; 1,000]$ & 613 & 24,7 \\
Moderate AMG level & moderate - high & $(0,600 ; 0,800]$ & 937 & 37,8 \\
& moderate - medium & $(0,551 ; 0,600]$ & 585 & 23,6 \\
The lowest AMG values & moderate - low & $(0,501 ; 0,550]$ & 309 & 12,5 \\
& difficult & $(0,201 ; 0,400]$ & 25 & 1,0 \\
& bad & {$[0,000 ; 0,200]$} & 2 & 0,1
\end{tabular}




\section{VERSITA}

\section{Population structure by economic age groups}

The crucial component of demographic potential, referring to municipalities, is the age structure of inhabitants which influences many demographic indicators, including e.g. birth rate. It also has substantive economic and developmental impact on regional development, manifested e.g. by the number of working age population, children who have to be provided with adequate education, senior citizens requiring care, including health care. Spatial diversification of municipalities, in terms of age dependency ratio values, is presented below (Fig. 6) and illustrates the relation of non-working age population number (women aged 0-17 and also 60 and more; as well as men aged 0-17 and also 65 and more against working age population number (women aged 18-59 and men aged 18-65). High values of age dependency ratio indicate the occurrence of an unfavourable relation between the number of working age population (potential workforce resources) and the non-working age population (covering the total of pre-working age population up to 17 years of age and post-working age population - women aged 60 and more and men aged 65 and more). In Poland, in 2011, 55.8 nonworking age persons fell per 100 working age ones. These values differ significantly if the division by gender is taken into account. The ratio for women presented much higher level (i.e. unfavourable one) and amounted to 69.0 women in non-working age per 100 females in working age, whereas in case of men the respective value was 43.8 .

The highest age dependency ratio values in 2011 were recorded in many municipalities of central, eastern and south-eastern Poland. The exceptionally high ratio values were observed in the following four urban municipalities of Łomżyński sub-region: Bielsk Podlaski, Orla, Dubicze Cerkiewne and Chyże. In case of these municipalities the ratio values were above 100 persons, which means that there are more nonworking age people than the working age ones. High values of age dependency ratio resulted mainly from the large number of production age population against the groups of pre- and postproduction age population.

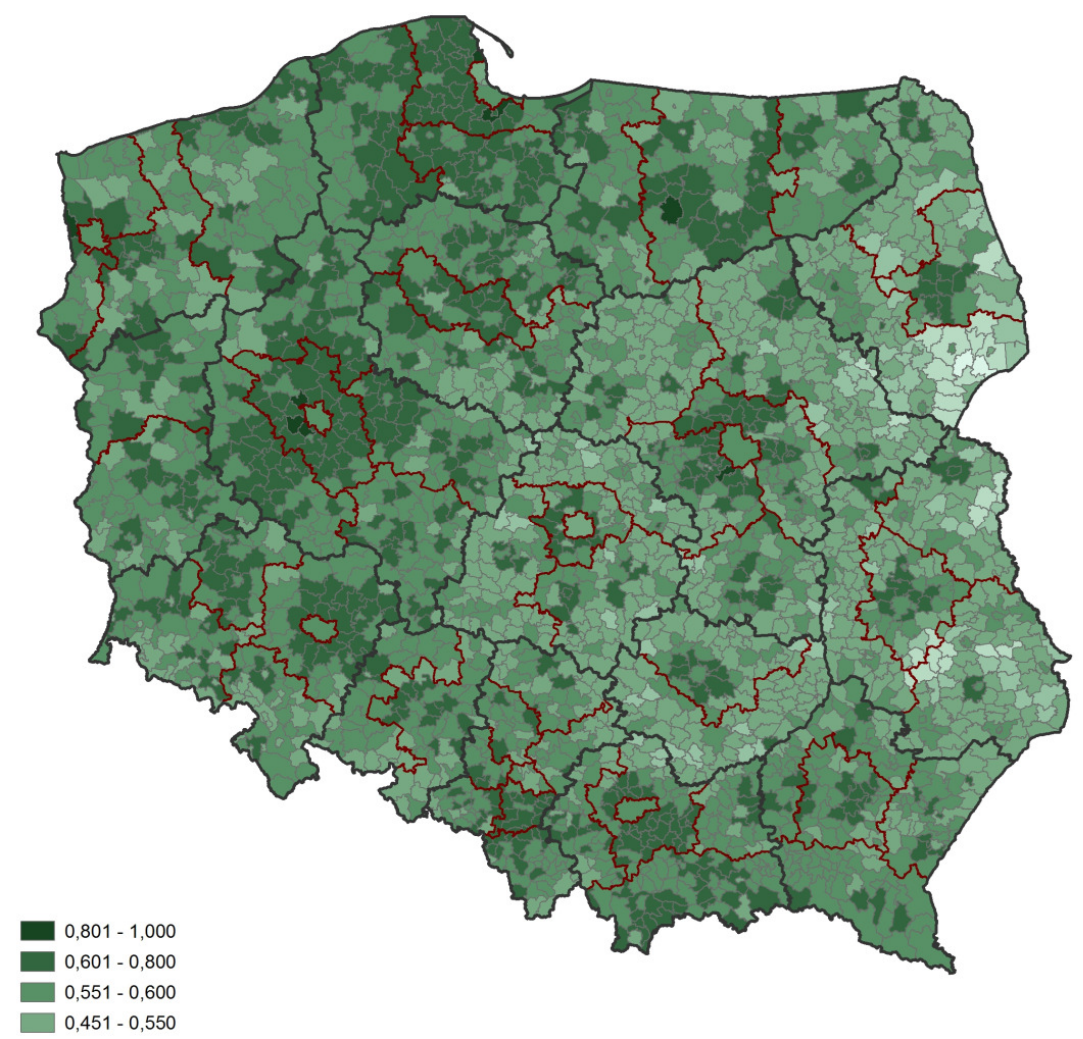

Fig. 7: Aggregate measure of growth in 2011. Source: Compilation based on the data available in the Local Data Bank of the Central Statistical Office. 
The lowest ratio values were recorded in the majority of Polish south-western, western and north-western municipalities. In 119 municipalities the ratio presented exceptionally low values (below 50), while in case of two below 40 and it referred to the urban-rural municipality of Łęczna (Lubelski sub-region) and urban municipality of Bełchatów (Piotrkowski sub-region).

\section{Demographic situation in municipalities - final remarks}

The overall assessment of demographic situation in municipalities in 2011 was performed based on the aggregate measure of growth (AGM), which was constructed having considered three aspects: migration net ratio per 10000 inhabitants, natural increase per 10000 inhabitants and age dependency ratio.

According to the information presented in Tab. 1 and Fig. 7 the situation in the vast majority of municipalities (73.9\%) can be defined as moderate. In $25.0 \%$ of municipalities the situation was either good or very good, whereas in case of $1.1 \%$ of municipalities (i.e. in 27 units) the situation was either difficult or bad.

The demographic situation in municipalities was greatly diversified depending on the territory. The highest AMG values were recorded in many municipalities located in the direct vicinity of large urban centres and among them in the following sub-regions: Gdański, Poznański, Bydgosko-Toruński, Nowosądecki, Tyski and Starogardzki. The situation of municipalities in Poznański sub-region was positively assessed, since all of them were included in the classes characterized by very good, good or moderately high level of demographic growth (in the first three classes). About $84 \%$ (i.e. 31 out of 37 ) municipalities belonged to the class featuring the highest AMG values indicating very good or good demographic potential. Three of them were ranked among the first ten: Komorniki, Dopiewo and Rokietnica. The situation of Gdański subregion municipalities was similar (all municipalities were included in the first three classes of demographic growth and $79 \%$ of them, i.e. 30 out of 38 were listed in the first two classes characterized by the highest AGM values).
Among cities with district rights the highest demographic growth potential was recorded in the following cities: Żory (position 236), Rzeszów (position 265), Biała Podlasks (position 389) and Siedlce (position 390).

The lowest AGM values, indicating areas characterized by low developmental potential, were reported in many municipalities of central Poland (located in Sandomierski-Jędrzejowski sub-region), eastern Poland (selected municipalities of the following sub-regions: Łomżyńki, Chełmsko-Zamojski, Białostocki) and some municipalities in Opolskie region. E.g. 48\% in each of Łomżyński and SandomierskiJędrzejowski sub-region municipalities were covered by the classes presenting the lowest level of demographic growth (characterized by bad, difficult or moderately low situation). Among cities with district rights the lowest ranking positions were occupied by the following cities: Sopot (position 2242), Lodz (position 2162) and Jelenia Góra (position 1996).

\section{References}

Hellwig Z (1968) Zastosowanie metody taksonomicznej do typologicznego podziału krajów ze względu na poziom ich rozwoju oraz zasoby i strukturę wykwalifikowanych kadr [Taxonomic method application for the typological division of countries in terms of their development level and structure of qualified personnel]. Statistical Review Bulletin. 4: 307-327.

Dziechciarz J (2003 ed.), Ekonometria. Metody, przykłady, zadania [Econometrics. Methods, examples, problems], University of Economics in Wrocław Publishing House, Wrocław.

Walesiak M (2006), Uogólniona miara odległości w statystycznej analizie wielowymiarowej [The generalized distance measure in statistical multivariate analysis], University of Economics in Wrocław Publishing House.

Bal-Domańska B, Wilk J (2011) Gospodarcze aspekty zrównoważonego rozwoju województw wielowymiarowa analiza porównawcza [Economic aspects of regional sustainable development multivariate comparative analysis]. Statistical Review 3-4: 300-322. 